\title{
Sintering of Ni-Zn Ferrite Nanopowders By the \\ Constant Heating Rate (Chr) Method
}

\author{
Ana Cristina Figueiredo de Melo Costa ${ }^{\mathrm{a}}$, Edener Tortella ${ }^{\mathrm{b}}$, Elias Fagury Neto ${ }^{\mathrm{b}}$, \\ Márcio Raymundo Morelli ${ }^{\mathrm{b}}$, Ruth Herta Goldschmidt Aliaga Kiminami ${ }^{\mathrm{b}}$ \\ ${ }^{a}$ Department of Materials Eng., Federal University of Campina Grande, \\ 58109 - 970 Campina Grande - SP, Brazil \\ ${ }^{\mathrm{b}}$ Department of Materials Eng., Federal University of São Carlos, \\ 13565-905 São Carlos - SP, Brazil
}

Received: January 30, 2003; Revised: June 30, 2004

\begin{abstract}
The constant heating rate method employed in sintering studies offers several advantages over the isothermal method, particularly the fact that all the parameters that describe the sintering phenomena can be obtained from a single sample. The purpose of this work is to determine the parameters of sintering kinetics of nanosized Ni-Zn ferrite powders synthesized by combustion reaction. The nonisothermal sintering method was studied using a constant heating rate (CHR). The Ni-Zn ferrite powders, with average particle size varying from $18 \mathrm{~nm}$ to $29 \mathrm{~nm}$, were uniaxially pressed and sintered in an horizontal dilatometer at a constant heating rate of $5.0^{\circ} \mathrm{C} / \mathrm{min}$ from 600 ${ }^{\circ} \mathrm{C}$ up to complete densification, which was reached at $1200^{\circ} \mathrm{C}$. The compacts were characterized by scanning electron microscopy (SEM). Experimental results revealed three different sintering stages, which were identified through the Bannister Theory. The shrinkage and the shrinkage rate analyzed showed a viscous contribution in the initial sintering stage, which was attributed to the mechanism of structural nanoparticle rearrangement.
\end{abstract}

Keywords: Ni-Zn ferrite, sintering, nanoparticle

\section{Introduction}

The sintering of ferrites via solid state, as well as of other ceramic materials, is a thermal process that causes reduction of the surface area through the formation of grain boundaries, neck growth between particles and usually also densification. During the solid state sintering process, the porosity decreases and the material's microstructure, which defines the performance of the final product, is developed. The sintering stages represent the geometrical evolution that occurs during the transformation of a compact powder into a dense and resistant solid ${ }^{1,2}$. During these stages, the overall interface free energy of a set of particles decreases because the reduction of solidvapor interface energy is greater than the increase of solid-solid interface energy (grain boundary) of the sys$t^{3}{ }^{3}$. The driving force of the sintering process is the reduction of overall free energy by the decrease of specific surface area and compact interfaces. Solid state sintering may be performed by two alternative processes: densification, with a change of the solid-vapor interface

*e-mail: anacristina@dema.ufcg.edu.br

Article presented at the XV CBECIMAT, Natal - RN, November/2002 (particle-pore) into solid-solid interface with less energy, or grain growth, with the transformation of numerous small grains (the compact's particles) into a smaller number of large grains. From this standpoint, therefore, the microstructural changes that occur during solid sate sintering result from the combined effect of densification and grain growth ${ }^{4}$.

The sintering kinetics of ceramic materials was investigated here using the nonisothermal method, i.e., the constant heating rate (TCA or CHR). Compared to conventional isothermal sintering, this method yields faster results and requires only one sample, also allowing for an examination of the entire sintering history ${ }^{5}$. The nonisothermal techniques for analysis of the sintering stage initially allow for the determination of sintering parameters such as the sintering coefficient, activation energy and diffusion sintering ${ }^{6}$. Starting from the basic sintering equation, Woolfrey and Bannister ${ }^{7,8}$ proposed a series of Arrhenius-like equations for the study of constant heating 
rate (CHR) sintering, suggesting the following equation:

$$
T^{2} \frac{d}{d t}\left(\frac{\Delta L}{L_{o}}\right)=\left(\frac{Q}{(n+1) R}\right)\left(\frac{\Delta L}{L_{o}}\right)
$$

where $\mathrm{T}$ is the temperature $(\mathrm{K}), d\left(\left(\Delta L / L_{o}\right) / d t\right.$ is the linear shrinkage differential, $\Delta L / L_{o}$ is the linear shrinkage (\%), $Q$ is the activation energy ( $\mathrm{kJ} / \mathrm{mol}), R$ is the ideal gas constant $(\mathrm{J} / \mathrm{mol} . \mathrm{K})$, and $n$ is the sintering mechanism. Based on Eq. 1, a $T^{2} d\left(\Delta L / L_{o}\right) / d t v s$. $\left(\Delta L / L_{o}\right)$ plot should consist of a straight line with an angular coefficient $Q /(n+1) R$, in which $Q /(n+1)$ may be calculated. In order to obtain the $n$ value, the activation energy $Q$ must be calculated by the Dorn method ${ }^{9}$. Once $Q$ has been calculated, $n$ can be determined and the sintering mechanism, which acts in the sintering stages, identified as shown in Table 1.

Several current scientific research efforts in the field of ceramic technology of ferrites by solid-state reaction study these materials, behavior during sintering by attempting to gain a better understanding of the mechanisms and phenomena involved in grain densification and growth. This knowledge is important to allow changes in the composition and processing of ferrites to be effected, with the purpose of obtaining microstructures that confer on the sintered material properties and characteristics appropriate for their application. Some of these studies are the following: Levesque ${ }^{10}$ and Paulus ${ }^{11,12}$ studied the grain growth of $\mathrm{Mn}-\mathrm{Zn}$ ferrites in the early stage of sintering; Jain et al. ${ }^{13}$ reported on grain growth kinetics in the intermediate stage of $\mathrm{Mn}-\mathrm{Zn}-\mathrm{Fe}$ ferrite sintering, which was obtained by the conventional oxide blending method. The activation energy determined for the intermediate stage was $130 \mathrm{Kcal} / \mathrm{mol}$; Dias et al. ${ }^{3}$ investigated the sintering kinetics of the intermediate and final stages of Ni-Zn ferrites prepared by hidrothermal synthesis; Parvatheeswara Rao et al. ${ }^{14}$ studied the evolution of $\mathrm{Ni}$ $\mathrm{Zn}$ ferrite microstructures at sintering temperatures in the range of $1150{ }^{\circ}$ to $1300{ }^{\circ} \mathrm{C}$ for 1 to $4 \mathrm{~h}$. Densification and grain growth was reported as Arrhenius rate controlled processes with activation energies of 63.9 and 64.4 $\mathrm{Kcal} / \mathrm{mol}$, respectively. Cho et al. ${ }^{15}$ investigated the behavior during sintering of nanocrystalline Ni-Zn ferrites, chemically modified by the addition of $\mathrm{Si}$ and $\mathrm{Ca}$. The activation energy estimated for grain boundary

Table 1. Sintering mechanism according to Wooffrey and Bannis$\operatorname{ter}^{7,8}$.

\begin{tabular}{cc}
\hline $\mathrm{n}$ & Sintering Mechanism \\
\hline 0 & Viscous flow \\
1 & Bulk diffusion \\
2 & Grain boundary diffusion \\
\hline
\end{tabular}

diffusion was $310 \mathrm{~kJ} / \mathrm{mol}$ and $470 \mathrm{~kJ} / \mathrm{mol}$, respectively, for Ni-Zn ferrites with and without additives. An activation energy of $750 \mathrm{~kJ} / \mathrm{mol}$ was calculated for micrometric $\mathrm{Ni}-\mathrm{Zn}$ ferrite powders.

The above-mentioned studies investigated the sintering kinetics throughout the sintering stages of this material. However, no reports appear to be available regarding specific research work on the sintering kinetics of $\mathrm{Ni}_{0.7} \mathrm{Zn}_{0.3} \mathrm{Fe}_{2} \mathrm{O}_{4}$ ferrites synthesized by combustion reaction. Hence, by means of the nonisothermal, constant heating rate (CHR) method, this study aimed to evaluate the effect of $\mathrm{Zn}^{2+}$ concentrations on the sintering kinetics of $\mathrm{Ni}_{1-\mathrm{x}} \mathrm{Zn}_{\mathrm{x}} \mathrm{Fe}_{2} \mathrm{O}_{4}$ nanometric powder with $\mathrm{x}=0.3 ; 0.5 ; 0.7 \%$ mol of $\mathrm{Zn}^{2+}$ obtained by combustion reaction.

\section{Experimental}

To synthesize ferrite powders by combustion reaction, $\mathrm{Ni}\left(\mathrm{NO}_{3}\right)_{2} \cdot 6 \mathrm{H}_{2} \mathrm{O}, \mathrm{Zn}\left(\mathrm{NO}_{3}\right)_{2} \cdot 6 \mathrm{H}_{2} \mathrm{O}$, and $\mathrm{Fe}\left(\mathrm{NO}_{3}\right)_{3} \cdot 9 \mathrm{H}_{2} \mathrm{O}$ were used as precursor reagents (oxidizing agents) and cation sources and urea $\left(\mathrm{CO}\left(\mathrm{NH}_{2}\right)_{2}\right)$ as the reducing agent. The procedure used to synthesize the powders by combustion reaction has been described in detail in previous reports ${ }^{16,18}$. Powders with particle sizes ranging from 18 to $29 \mathrm{~nm}$ were compacted into $9.8 \mathrm{~mm}$ diameter, $3 \mathrm{~mm}$ high pellets by uniaxial pressing at $385 \mathrm{MPa}$ (green density $59.1 \pm 0.98$ of theoretical density). The samples, which were named $\mathrm{C} 03, \mathrm{C} 05$ and $\mathrm{C} 07$ for systems with $0.3,0.5$ and $0.7 \% \mathrm{~mol}$ of $\mathrm{Zn}^{2+}$, respectively, were calcined at $600{ }^{\circ} \mathrm{C} / 1 \mathrm{~h}$ for binder burnout (5\% PVAL) and then sintered at $1200^{\circ} \mathrm{C}$ in a NETZCHS 402E dilatometer at a constant heating rate of $5{ }^{\circ} \mathrm{C} / \mathrm{min}$. After sintering, the samples were polished with $0.3 \mu \mathrm{m}$ alumina, thermally etched at $1100{ }^{\circ} \mathrm{C}$ for $30 \mathrm{~min}$, and then analyzed by SEM (XL30 FEG, Philips). Representative micrographs of the samples were used to determine the mean grain size using the MOCHA software program (Jandel, Image Analyzer).

\section{Results and Discussion}

The early, intermediate and final stages of Ni-Zn ferrite sintering were evaluated to investigate the effect of the concentration of $\mathrm{Zn}^{2+}$ on the sintering of nanometric powders of Ni-Zn ferrites synthesized by combustion reaction. Figs. $1 \mathrm{a}$ and $\mathrm{b}$ and Table 2 show the results obtained for linear shrinkage $\left(\Delta \mathrm{L} / \mathrm{L}_{0}\right)$ and linear shrinkage rate $\left(\mathrm{d}\left(\Delta \mathrm{L} / \mathrm{L}_{\mathrm{o}}\right) / \mathrm{dt}\right)$ according to temperature, for systems $\mathrm{C} 03, \mathrm{C} 05$ and $\mathrm{C} 07$, which corresponded, respectively, to $0.3,0.5$ and $0.7 \mathrm{~mol}$ of $\mathrm{Zn}^{2+}$. Increases in the concentration of $\mathrm{Zn}^{2+}$ affected the sintering behavior, reducing the linear shrinkage at the point of maximum linear shrinkage and final density of the samples. The $\mathrm{C} 03$ and $\mathrm{C} 05$ systems displayed similar values of temperature at the 
maximum linear shrinkage rate $\left(1016^{\circ} \mathrm{C}\right)$, although the C05 system showed a lower maximum linear shrinkage rate $(1.9 \mathrm{E}-11 / \mathrm{min})$ than the $\mathrm{C} 03$ system $(3.3 \mathrm{E}-11 / \mathrm{min})$.

The temperature for the onset of retraction $\left(814{ }^{\circ} \mathrm{C}\right)$ was found to be higher in the $\mathrm{C} 07$ system than in the $\mathrm{C} 03$ and $\mathrm{C} 05\left(787{ }^{\circ} \mathrm{C}\right.$ and $\left.763{ }^{\circ} \mathrm{C}\right)$ systems. On other hand, the temperature at the point of maximum linear shrinkage $\left(978^{\circ} \mathrm{C}\right)$ for $\mathrm{C} 07$ was lower than in the other systems $\left(1016^{\circ} \mathrm{C}\right)$. The point of maximum linear shrinkage decreased according to the $\mathrm{Zn}^{2+}$ concentration in the system; in other words, the shrinkage in the C07 system $\left(0.7 \%\right.$ mol of $\left.\mathrm{Zn}^{2+}\right)$ was $5.86 \%$ ( $73.1 \%$ of theoretical density), whereas it was $8.08 \%$ ( $72,21 \%$ of theoretical density) in the C05 system and $9.96 \%$ (81.72\% of theoretical density) in the $\mathrm{C} 03$ system. The same behavior was observed for retraction at the final temperature $\left(1200{ }^{\circ} \mathrm{C}\right)$, i.e., $11.88 \%$ ( $89.13 \%$ of theoretical density), $13.68 \%$ (93.23\% of theoretical density) and $14.48 \%$ (95.38\% of theoretical density), respectively, for the $\mathrm{C} 07, \mathrm{C} 05$ and C03 systems.

Figure 2 shows the plot calculated by Woolfrey and Bannister's method ${ }^{7,8}$, to determine the sintering coeffi-

Table 2. Results of sintering at $1200{ }^{\circ} \mathrm{C}$ for the $\mathrm{C} 03, \mathrm{C} 05$ and $\mathrm{C} 07$ systems with a constant heating rate of $5{ }^{\circ} \mathrm{C} / \mathrm{min}$.

\begin{tabular}{|c|c|c|c|}
\hline Systems & $\begin{array}{c}\mathrm{C} 03 \\
\mathrm{Ni}_{0.7} \mathrm{Zn}_{0.3} \mathrm{Fe}_{2} \mathrm{O}_{4}\end{array}$ & $\begin{array}{c}\mathrm{C} 05 \\
\mathrm{Ni}_{0.5} \mathrm{Zn}_{0.5} \mathrm{Fe}_{2} \mathrm{O}_{4}\end{array}$ & $\begin{array}{c}\mathrm{C} 07 \\
\mathrm{Ni}_{0.3} \mathrm{Zn}_{0.7} \mathrm{Fe}_{2} \mathrm{O}_{4}\end{array}$ \\
\hline $\begin{array}{l}\text { Starting shrinkage } \\
\text { temperature }\left({ }^{\circ} \mathrm{C}\right)\end{array}$ & 787 & 763 & 814 \\
\hline $\begin{array}{l}\text { Temperature at the point of } \\
\text { maximum linear shrinkage }\left({ }^{\circ} \mathrm{C}\right)\end{array}$ & 1016 & 1016 & 978 \\
\hline $\begin{array}{l}\text { Shrinkage rate at the point } \\
\text { of maximum linear } \\
\text { shrinkage rate }(1 / \mathrm{min})\end{array}$ & $3.35 \mathrm{E}-1$ & $1.93 \mathrm{E}-1$ & $2.22 \mathrm{E}-1$ \\
\hline $\begin{array}{c}\text { Shrinkage at the point of maximum } \\
\text { linear shrinkage rate }(\%)\end{array}$ & 9.96 & 8.08 & 5.86 \\
\hline $\begin{array}{l}\text { Linear shrinkage at the point of } \\
\text { maximum linear shrinkage rate }(\%)\end{array}$ & 81.72 & 77.21 & 73.10 \\
\hline Linear shrinkage at $1200{ }^{\circ} \mathrm{C}(\%)$ & 14.48 & 13.68 & 11.88 \\
\hline Relative density at $1200^{\circ} \mathrm{C}(\%)$ & 95.38 & 93.23 & 89.13 \\
\hline
\end{tabular}

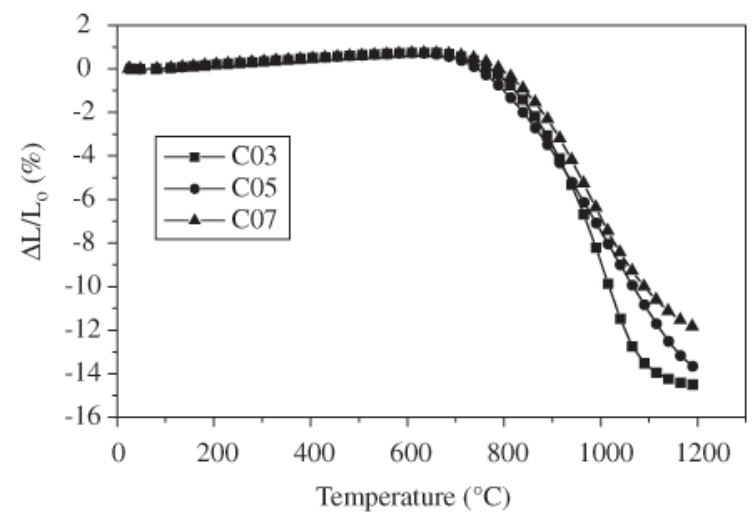

(a)

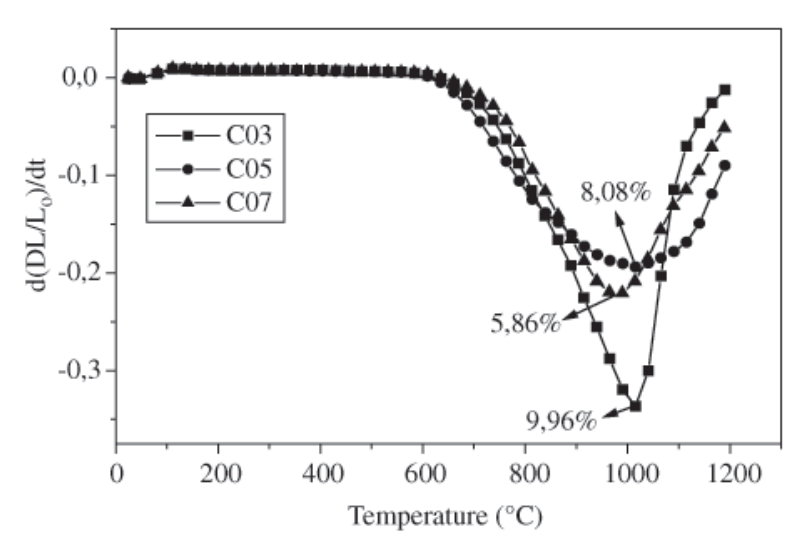

(b)

Figure 1. Sintering results obtained for the $\mathrm{C} 03, \mathrm{C} 05$ and $\mathrm{C} 07$ systems; a) linear shrinkage, b) linear shrinkage rate, both in terms of temperature, with a constant heating rate of $5^{\circ} \mathrm{C} / \mathrm{min}$. 
cients with a constant heating rate $(\mathrm{CHR})$ of $5^{\circ} \mathrm{C} / \mathrm{min}$, for the early, intermediate and final stages. The activation energy was determined by the Dorn method ${ }^{9}$. Table 3 shows the values of activation energy and sintering coefficients for the three stages of sintering. The linear part of the curve represents the stages in which probably only one sintering mechanism took place, while the nonlinear part represents a transition region between two mechanisms.

The initial stage developed to $2.5 \%$ in the three systems investigated. The activation energy values ranged from 214.61 to 242.70 and the sintering mechanism was $n \sim 0$, indicating that the prevailing mechanism in the initial stage of sintering in the three systems was structural rearrangement of nanoparticles, with viscous flow characteristics $(n=0)$. The activation energy values were lower than those estimated by Cho et al. ${ }^{15}$ for grain boundary diffusion, which were $310 \mathrm{~kJ} /$ $\mathrm{mol}$ and $470 \mathrm{~kJ} / \mathrm{mol}$ for Mn-Zn ferrite nanopowders.

The second stage ranged from $3.0 \%$ to $10.0 \%$ in $\mathrm{C} 03$, $3.0 \%$ to $8.0 \%$ in $\mathrm{C} 05$, and $3.0 \%$ to $6.0 \%$ in C07. It was found, in this stage, that the nanoparticles also simulated a viscous

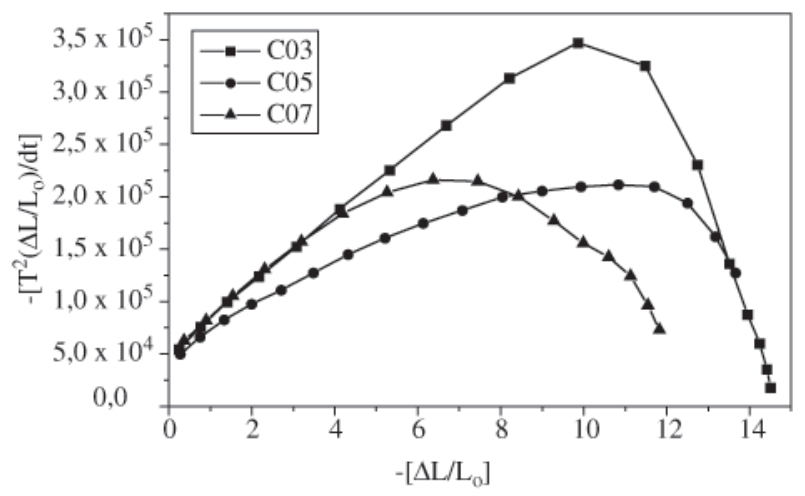

Figure 2. $\mathrm{T}^{2}\left(\Delta \mathrm{L} / \mathrm{L}_{\mathrm{o}}\right) / \mathrm{dt} v s . \Delta \mathrm{L} / \mathrm{L}_{\mathrm{o}}$ calculated through Bannister's equation. for systems $\mathrm{C} 03, \mathrm{C} 05$ and $\mathrm{C} 07$ with a constant heating rate of $5^{\circ} \mathrm{C} / \mathrm{min}$. flow behavior, as in the initial stage, owing to the presence of nanoparticles. However, grain boundary diffusion was believed to take place in this stage. The activation energy showed coherent values corresponding to the intermediate stage. In $\mathrm{C} 03$ and $\mathrm{C} 05$, these values $(130 \mathrm{~kJ} / \mathrm{mol})$ were lower than those proposed by Jain et al. ${ }^{13}$ for the sintering of Mn-Zn ferrites; nevertheless, $\mathrm{C} 07$ presented very similar values.

The third stage corresponded to the point of maximum linear shrinkage, coarsening, and decrease of the linear shrinkage rate due to a decrease of surface free energy. This stage ended when the final temperature was reached $\left(1200^{\circ} \mathrm{C}\right)$. It was observed that the primary mechanism was bulk diffusion $(n=1.0)$, owing to the nanometric size of the particles. Linear shrinkage rates of 9.96, 8.08 and $5.86 \%$ corresponded to the point of maximum linear shrinkage of $\mathrm{C} 03, \mathrm{C} 05$ and $\mathrm{C} 07$, respectively (Table 2). The activation energy presented typical values for this stage, ranging from $35.22 \mathrm{~kJ} / \mathrm{mol}$ to $45.06 \mathrm{~kJ} / \mathrm{mol}$.

Figures 3, 4 and 5 depict the sintering process of $\mathrm{C} 03$, C05 and C07 through SEM micrographs. Figures 3a, 3b and $3 \mathrm{c}$ show the linear shrinkage $\left(\Delta \mathrm{L} / \mathrm{L}_{0}\right)$ at $800{ }^{\circ} \mathrm{C}$ (initial stage) for $\mathrm{C} 03, \mathrm{C} 05$ and $\mathrm{C} 07$, which correspond to the following linear shrinkage hates: $0.58 ; 1.15$; and $0.23 \%$, respectively. In this test configuration it was observed that the early stage of neck growth occurred between two particles. This level coincided with the initial stage, in which the structural rearrangement of nanoparticles with a viscous flow characteristic is dominant.

Figures $4 \mathrm{a}, 4 \mathrm{~b}$ and $4 \mathrm{c}$ show the microstructures of $\mathrm{C} 03$, $\mathrm{C} 05$ and $\mathrm{C} 07$ at $1000{ }^{\circ} \mathrm{C}$, which corresponds to the temperature at which the maximum linear retraction occurred (end of intermediate stage). From this point on, grain growth took place owing to decreasing surface free energy. The linear shrinkage and average grain size found at this temperature were $9.19 ; 7.52$ and $6.89 \%$ and $0.17 \pm 0.81 \mu \mathrm{m} ; 0.18 \pm 0.93$ $\mu \mathrm{m}$ and $0.19 \pm 0.82 \mu \mathrm{m}$ for $\mathrm{C} 03, \mathrm{C} 05$ and $\mathrm{C} 07$, respectively.

Figures $5 \mathrm{a}, \mathrm{b}$ and $\mathrm{c}$ show the microstructures of the systems $\mathrm{C} 03, \mathrm{C} 05$ e $\mathrm{C} 07$ at $1100{ }^{\circ} \mathrm{C}$. In this temperature the

Table 3. Sintering parameters with a constant heating rate $(\mathrm{CHR})$ of $5{ }^{\circ} \mathrm{C} / \mathrm{min}$ for $\mathrm{C} 03, \mathrm{C} 05$ and $\mathrm{C} 07$ sintered at $1200{ }^{\circ} \mathrm{C}$; $\mathrm{Q}=$ activation energy, $\mathrm{n}=$ sintering coefficient.

\begin{tabular}{ccccc}
\hline Systems & Stages & $Q(\mathrm{~kJ} / \mathrm{mol})$ & $n$ & \\
\hline $\mathrm{C} 03$ & Initial & 242.70 & -0.1877 \\
$\mathrm{Ni}_{0.7} \mathrm{Zn}_{0.3} \mathrm{Fe}_{2} \mathrm{O}_{4}$ & Intermediate & 106.65 & -0.566 \\
& End & 35.44 & -1.417 \\
$\mathrm{C} 05$ & Initial & 214.61 & -0.1023 \\
$\mathrm{Ni}_{0.5} \mathrm{Zn}_{0.5} \mathrm{Fe}_{2} \mathrm{O}_{4}$ & Intermediate & 74.45 & -0.3095 \\
& End & 35.22 & -1.088 \\
$\mathrm{C} 07$ & initial & 224.39 & -0.2579 \\
$\mathrm{Ni}_{0.3} \mathrm{Zn}_{0.7} \mathrm{Fe}_{2} \mathrm{O}_{4}$ & Intermediate & 136.45 & -0.2075 \\
& End & 45.06 & -1.181 \\
\hline
\end{tabular}


evolution of the grain growth is observed (coarsening) in the final of sintering. The linear shrinkage and the average grain size of certain grain was $13.89 ; 11.38$ and $10.45 \%$ and $0.44 \pm 0.15 \mu \mathrm{m} ; 0.35 \pm 0.13 \mu \mathrm{m}$ and $0.41 \pm 0.19 \mu \mathrm{m}$ for the systems $\mathrm{C} 03, \mathrm{C} 05$ and $\mathrm{C} 07$, respectively.

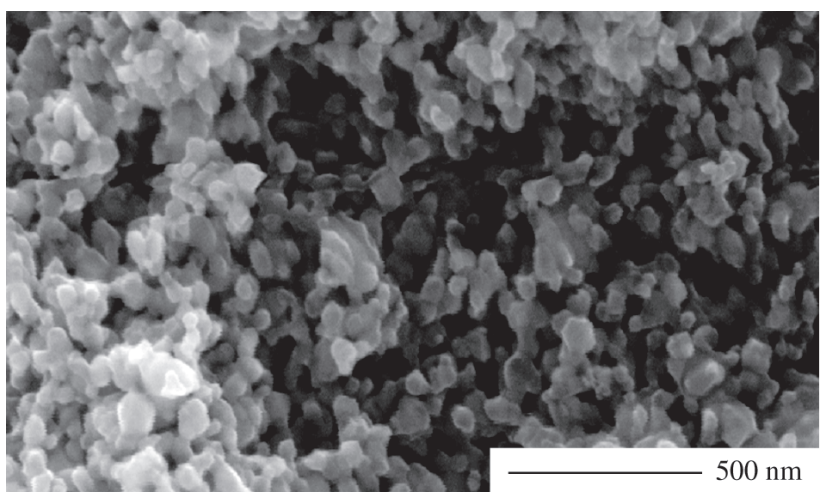

(a)

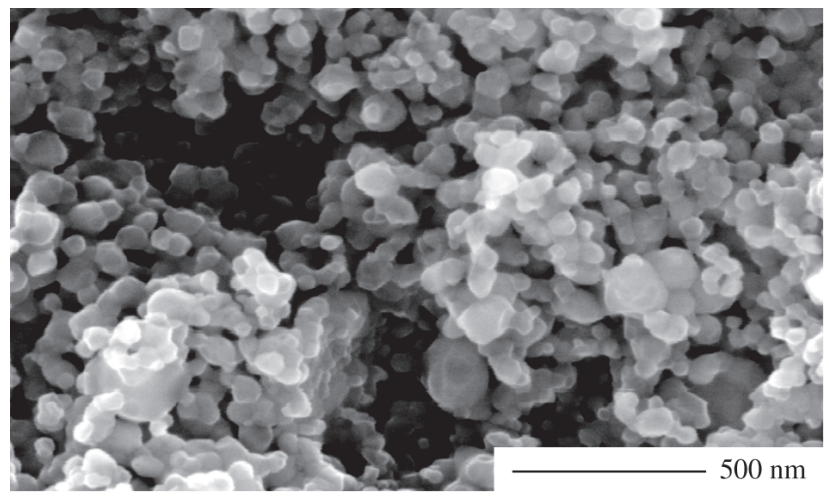

(b)

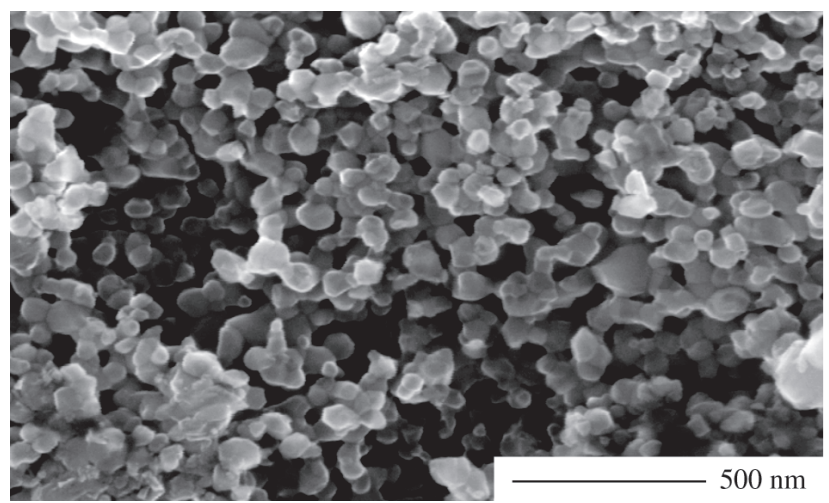

(c)

Figure 3. SEM Micrographs of a) $\mathrm{C} 03$, b) $\mathrm{C} 05$, c) $\mathrm{C} 07$ at $800{ }^{\circ} \mathrm{C}$, with a $\mathrm{CHR}$ of $5^{\circ} \mathrm{C} / \mathrm{min}$.

\section{Conclusions}

Based on the results of the investigation on sintering with a constant heating rate (CHR) reported on herein, the following conclusions were reached: (i) increases in $\mathrm{Zn}^{2+}$ content affected the sintering kinetics of $\mathrm{Ni}-\mathrm{Zn}$

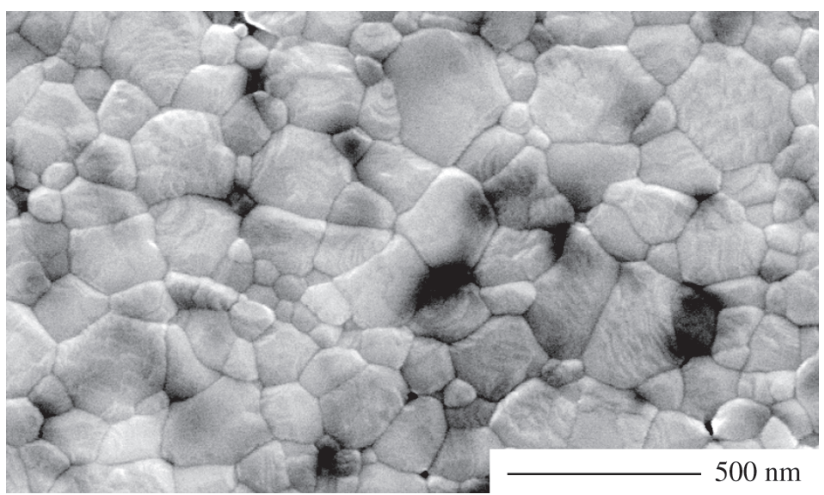

(a)

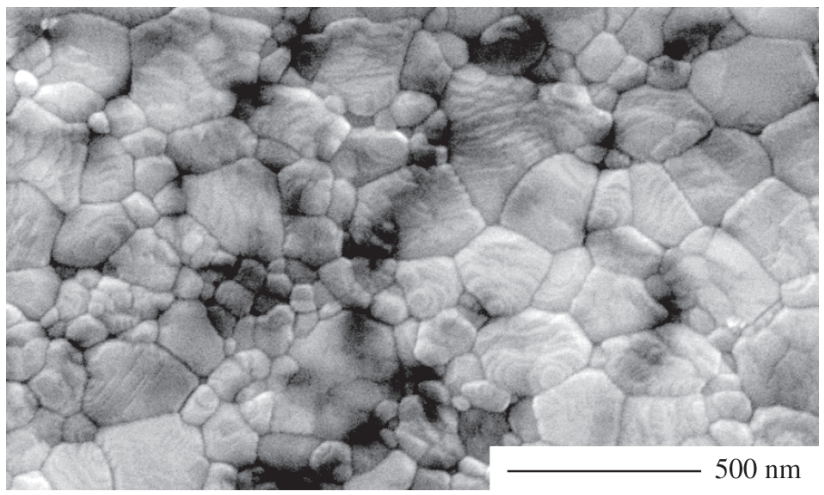

(b)

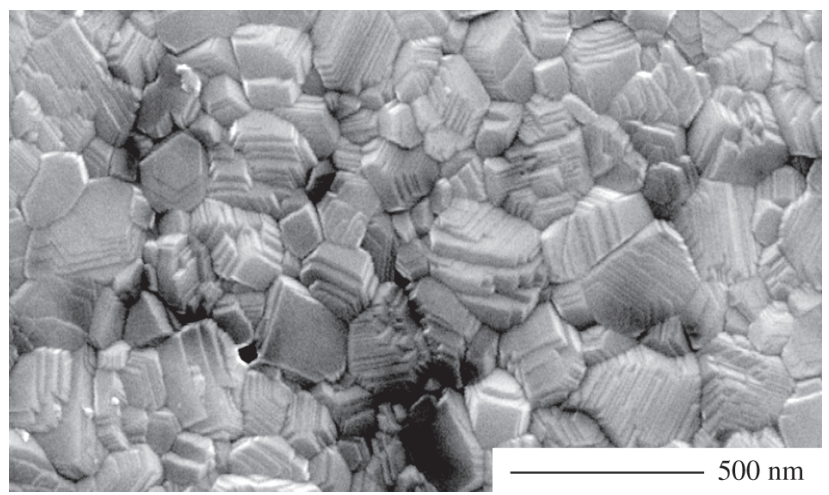

(c)

Figure 4. SEM Micrographs of: a) C03; b) C05; c) C07 at 1000 ${ }^{\circ} \mathrm{C}$, with a $\mathrm{CHR}$ of $5{ }^{\circ} \mathrm{C} / \mathrm{min}$. 


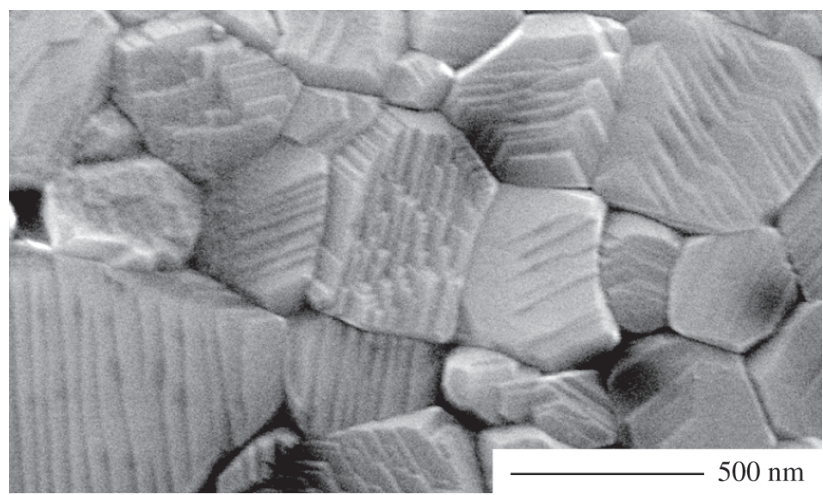

(a)

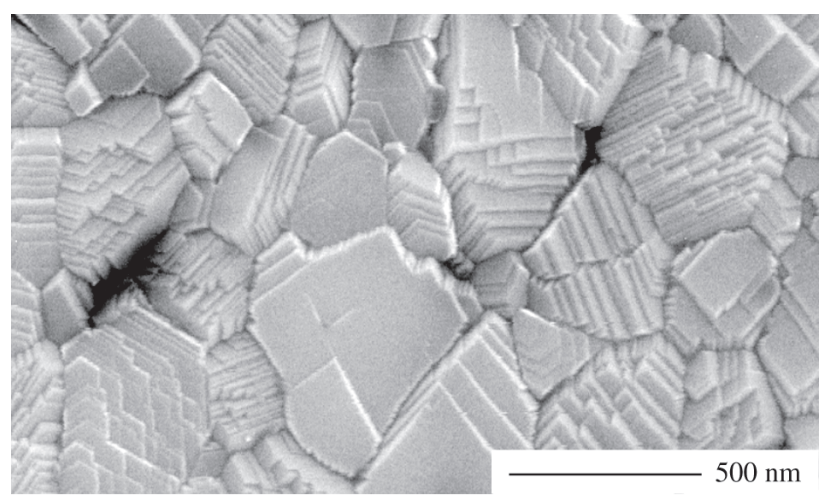

(b)

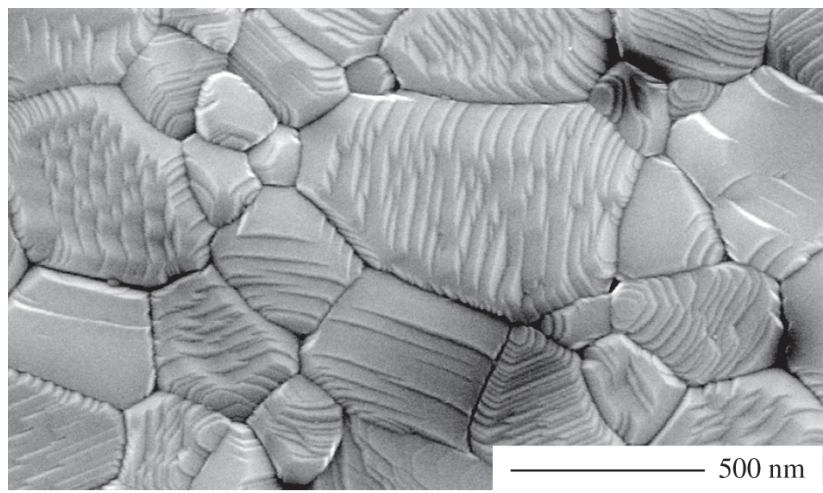

(c)

Figure 5. SEM micrographs of: a) C03; b) C05; c) C07 at 1100 ${ }^{\circ} \mathrm{C}$, with a $\mathrm{CHR}$ of $5{ }^{\circ} \mathrm{C} / \mathrm{min}$.

nanopowders, reducing the maximum densification rate and final density of the samples, but leaving the sintering mechanism unchanged; (ii) the sintering coefficient, calculated for the initial and intermediate stages of the three systems, was $\mathrm{n} \sim 0$, indicating that the predominant mechanism in these stages was structural rearrangement of nanoparticles, with a viscous flow characteristic; (iii) in the final stage, the predominant mechanism governing the sintering of nanopowders in the three systems was bulk diffusion ( $\mathrm{n} \sim$ 1).

\section{Acknowledgements}

We would like to thank the Brazilian institutions, FAPESP and CAPES for financial support.

\section{References}

1. Varela, J.A.; Longo, E. Cerâmica, v. 30, n. 172, p. 95102, 1994.

2. German, R.M. Sintering Theory and Practice. Ed. John Wiley \& Sons, New York, 1996.

3. Dias, A.; Mohallem, N.D.S.; Moreira, R.L. Mater. Res. Bull., v. 33, n. 3, p. 475-486, 1998.

4. Shaw, N.J. Advanced ceramics - Powder Metallurgy International, v. 21, n. 3, p. 16-20, 1989.

5. Leite, E.R.; Longo, E. Anais do $38^{\circ}$ CBC, v. 1, p. 126131, 1994.

6. Hillman, S.H.; German, R.M. J. Mater. Sci., v. 27, p. 2641-2648, 1992.

7. Woolfrey, J.L.; Bannister, M.J. J. Am. Ceram. Soc., v. 55, n. 12, p. 390-394, 1972.

8. Woolfrey, J.L. J. Am. Ceram. Soc., v. 55, n. 8, p. 383388, 1972.

9. Bacmann, J.J.; Cizeron, G. J. Am. Ceram. Soc., v. 51, n. 4, p. 209-212, 1968.

10. Levesque, P.; Gerlach, L.; Zneimer, J. Am. Ceram. Soc., v. 39, n. 3, p. 119-120, 1956.

11. Paulus, M. Phys. State Solid, v. 2, p. 1181-1196, 1962.

12. Paulus, M. Phys. State Solid, v. 2, p. 1325-1341, 1962.

13. Jain, G.C.; B.K. Das; Goel, N.C. Ind. J. Pure Appl. Phys., v. 14, p. 87-92, 1976.

14. Parvatheeswara Rao, B.; Subba Rao, P.S.V.; Rao, K.H. J. Phys. IV France, v. 7, p. C1-241-C1-242, 1997.

15. Cho, Y.S.; Schaffer, D.; Burdick, V.L.; Amarakoon, V. R.W. Mater. Res. Bull., v. 34, n. 14-15, p. 2361-2368, 1999.

16. Costa, A.C.F.M. et al., J. Mater. Sci. v. 37, p. 1-4, 2002.

17. Costa, A.C.F.M.; Tortella, E.; Morelli, M. R.; Kiminami R.H.G. A., J. Metas. and Nanocrys. Mater., v. 14, p. 57-64, 2002.

18. Kiminami, R.H.G.A., KONA Powder and Particle, v. 19 , p. $156-165,2001$. 
This article has received corrections in agreement with the ERRATUM published in Volume 8 Number 1. 